TITLE:

ON A NEW SPECIES OF LAMELLARIA (L. UTINOMII, N. SP.) FROM SHIRAHAMA, WAKAYAMA PREFECTURE, JAPAN (MOLL., GASTROPODA)

\author{
AUTHOR(S): \\ Taki, Iwao
}

CITATION:

Taki, Iwao. ON A NEW SPECIES OF LAMELLARIA (L. UTINOMII, N. SP.) FROM SHIRAHAMA, WAKAYAMA PREFECTURE, JAPAN (MOLL., GASTROPODA). PUBLICATIONS OF THE SETO MARINE BIOLOGICAL LABORATORY 1972, 21(1): 1-12

ISSUE DATE:

1972-12-01

URL:

http://hdl.handle.net/2433/175801

RIGHT: 


\title{
ON A NEW SPECIES OF LAMELLARIA (L. UTINOMII, N. SP.) FROM SHIRAHAMA, WAKAYAMA PREFECTURE, JAPAN (MOLL., GASTROPODA) ${ }^{1)}$
}

\author{
IWAO TAKI ${ }^{2)}$
}

\section{With Text-figures 1-18 and Plate I}

In 1960 a Gastropod specimen was handed over to me for study by Prof. H. Utinomi, Director of the Seto Marine Biological Laboratory of the Kyoto University. The present report is the result of observation on this specimen.

I wish to thank Prof. Utinomi for his kindness in giving me an opportunity to observe this specimen, in which peculiarity in the form of the radula was revealed. I am also grateful to Dr. T. Kuroda who kindly assisted me in studying the known species of this genus by his rich experience on the Molluscan fauna of Japan. I wish to thank Dr. G. M. Davis, of the Academy of Natural Sciences of Philadelphia, who kindly aided me in seeing the relevant literature.

\section{Lamellaria utinomii TAKI, new species}

(Plate I, Text-figs. 1-10)

Japanese name: Ibo bekkō-tamagai (new).

Shell (Text-figs. 1-4): thin and fragile, porcelainous and whitish, covered with a very thin buffish periostracum. Oval in outline, number of whorl $23 / 4$, spire low conic, apex roundly elevated and whorl rapidly increasing, suture deeply grooved; surface smooth, with numerous very fine growth striae. Aperture very wide, ellipsoid, columella very weak, simple, and there is seen a thin white callus $(2 \mathrm{~mm}$. wide) along the inner lip, peristome very thin and sharp, inner surface of the apex can be completely seen from within.

Holotype: Deposited in the museum of the Seto Marine Biological Laboratory, registering as SMBL-Type 237 (a-Animal, b-Shell).

Dimension: Height $23.0 \mathrm{~mm}$, width $26.0 \mathrm{~mm}$, major diam. $27.5 \mathrm{~mm}$, minor diam. $18.7 \mathrm{~mm}$.

1) Contributions from the Seto Marine Biological Laboratory, No. 564.

2) Address: 48 Nakayama-cho, Kamikamo, Kitaku, Kyoto.

Publ. Seto Mar. Biol. Lab., XXI (1), 1-12, 1972. (Article 1) 
Locality: Tōshima, $10 \mathrm{~m}$ in depth (rocky bottom), near the Seto Mar. Biol. Lab. of the Kyoto Univ., Shirahama, Wakayama Pref.

Date: 9th August, 1960. Collector: Mr. Tadashi Matsuoka.

Animal (Text-figs. 5-6): When in life, it was deep purplish black in colour, rather flat, with the dorsal surface wholly covered with scaly flat warts.

The specimen preserved in spirit $55 \mathrm{~mm}$ long, $25 \mathrm{~mm}$ wide, $20 \mathrm{~mm}$ high, is entirely buff in colour, the dorsal surface somewhat blackish. The entire body is occupied by the mantle, which is shrunken ventralwards and in dorsal view the outline is roughly hexagonal, the front side protruded and the hind side very weakly elongated. In

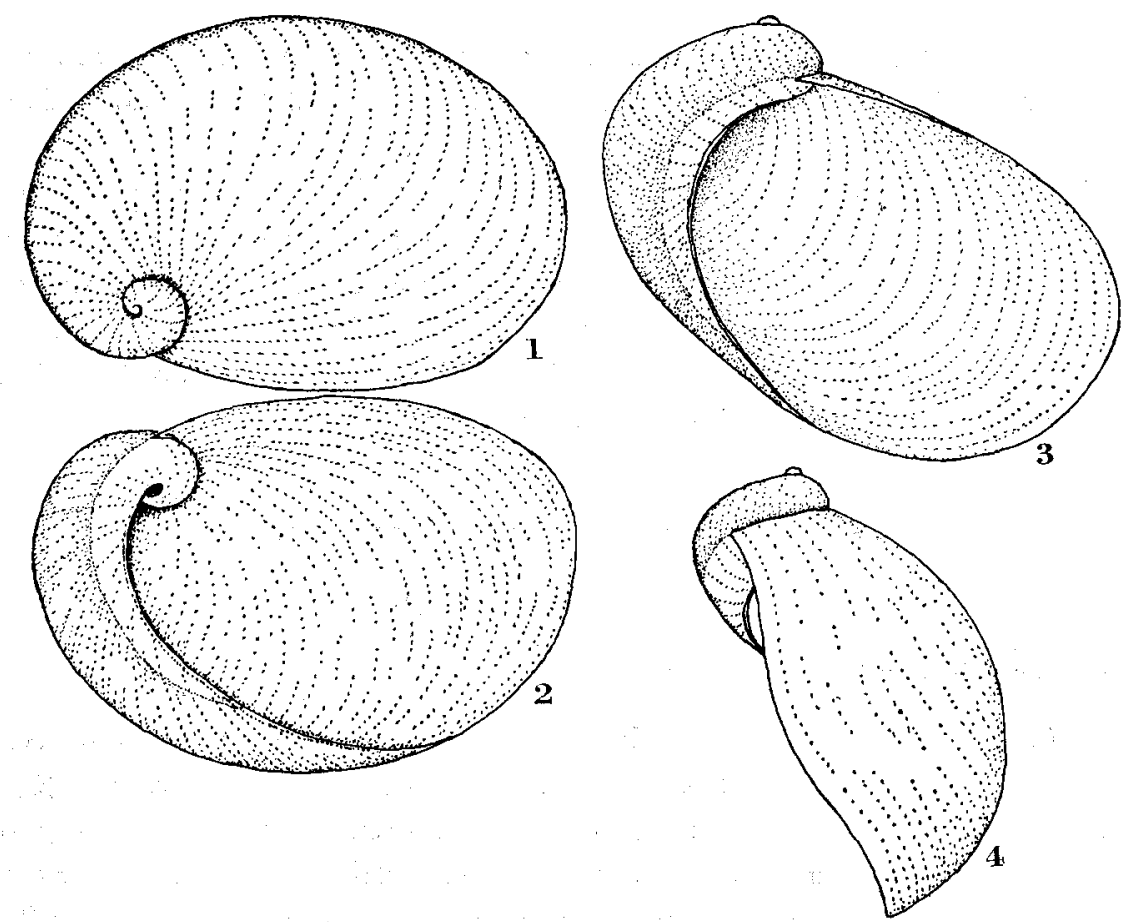

Text-figs. 1-4. Lamellaria utinomii Taki, n. sp. 1. dorsal view; 2. ventral view; 3. front view; 4, right side view. $\quad \times 2.1$

the front view the anterior part of the mantle is contracted like a siphon. The main part of the dorsum is roughly quadrate but there is no proper basis supporting this form. The dorsum is wholly covered with round-topped shrunken warts and rather tough to the touch.

In the ventral view the foot, $30 \mathrm{~mm}$ long and $12 \mathrm{~mm}$ wide, is rather small in comparison with the mantle. The head has two elongated flat tentacles which are sharply pointed, a very small rudimentary eye on the outer side of the tentacle near the tip, and a mouth opening which is especially swollen ventrally. There is a small 

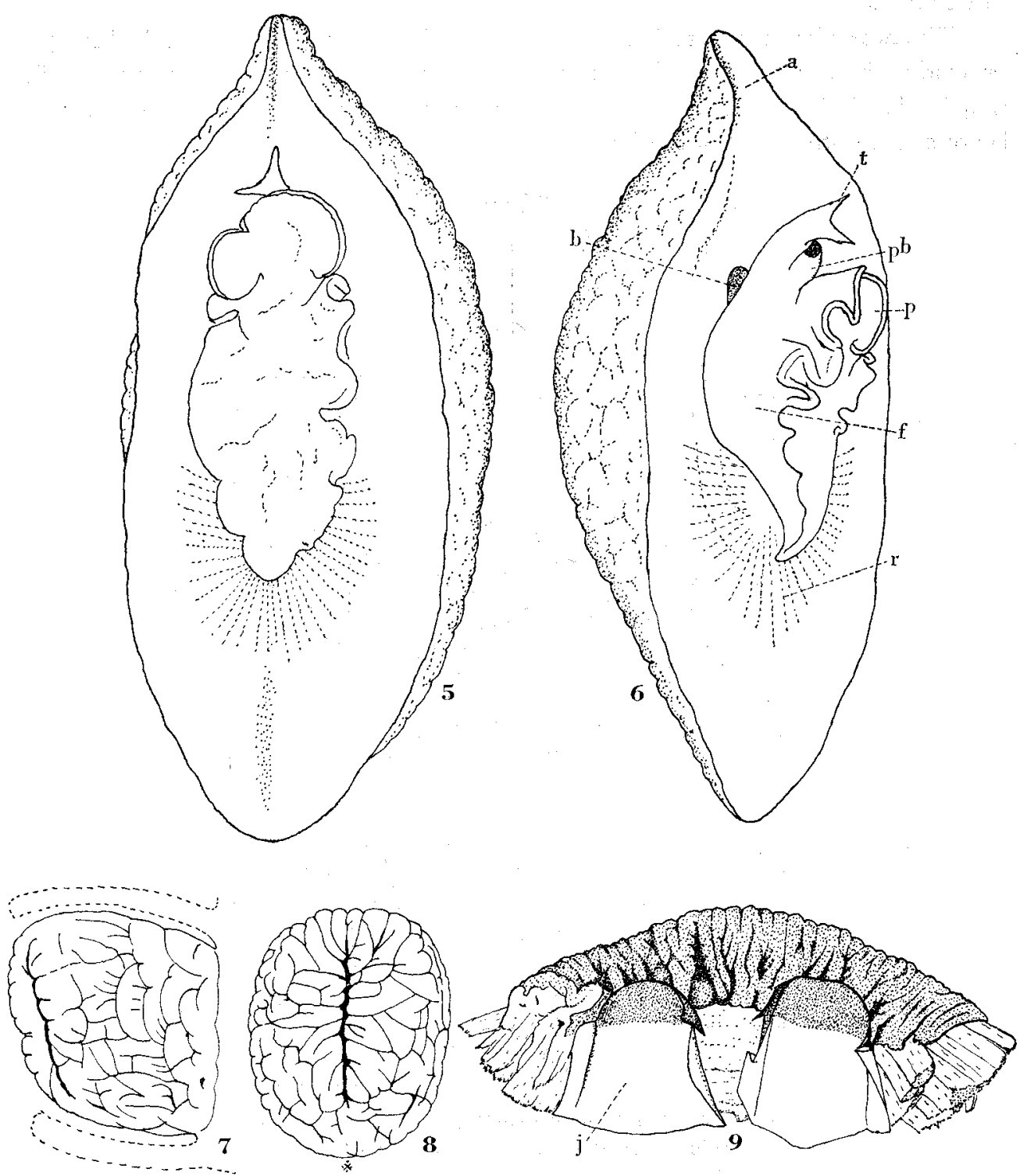

Text-figs. 5-9. Lamellaria utinomii Taki, n. sp. 5. Ventral view of the animal, $\times 2 ; 6$. right oblique view of the animal, $\times 2 ; 7$. left side view of proboscis; 8 . front view of the same; 9 . proboscis cut along the mid-ventral line (marked * in fig. 8 ) and opened to show jaw-plates lying inside. a. anterior siphon; b. branchial orifice; f. foot; j. jaw-plate; pb. proboscis; p. propodium; r. radial muscles; t. tentacle with eye. 
branchial orifice in the mantle, located above the head, through which the ctenidium can be seen.

The base of the foot is rather small in comparison with the sole area, the hind part protruding backward. The front part of the foot, occupying the anterior third of it, may be discriminated as a propodium, sharply demarcated by the double rim which is not seen in other part of the foot.

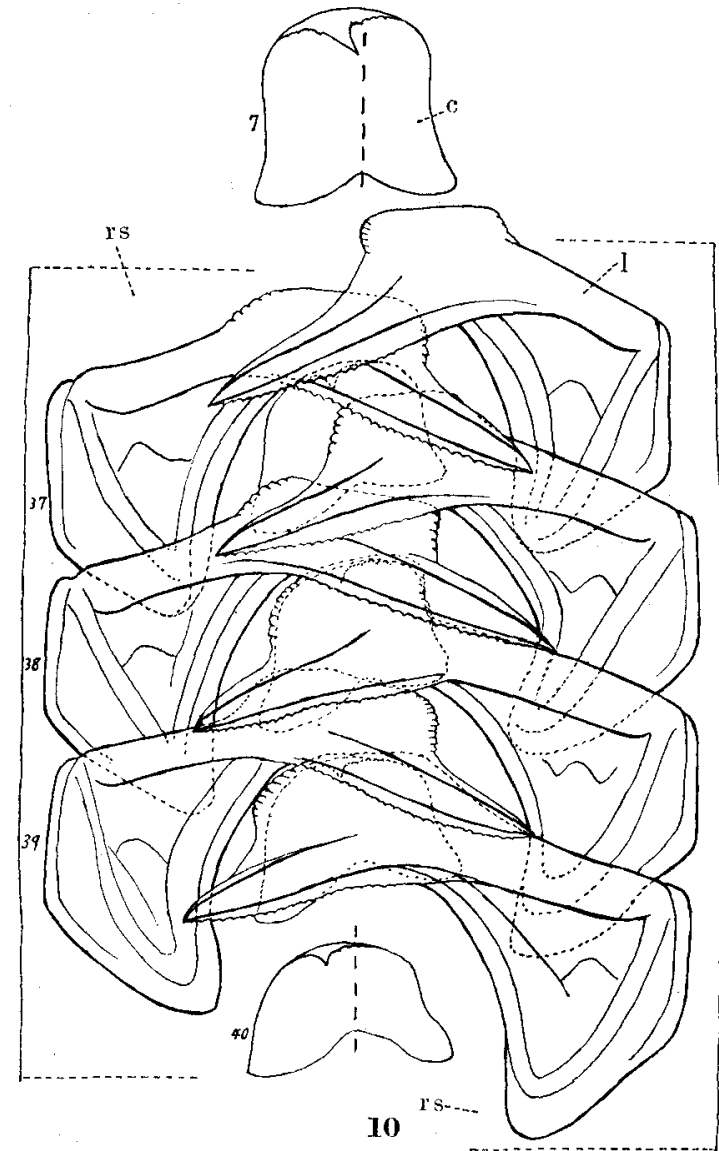

Text-fig. 10. Lamellaria utinomii Taki, n. sp. Median part of the radula; the serial number is shown on the left side of each tooth. $\times 30$

c. central tooth; 1. lateral tooth; rs. radular sheet.

Proboscis, completely withdrawn in the muscular sheath, $5.0 \mathrm{~mm}$ long and $5.5 \mathrm{~mm}$ high, dark greyish buff in colour. It is short conical, surface rugose with numerous wrinkles like a mammalian brain, laterally compressed, and the mouth is shown by a vertical slit. A longitudinal cut at the bottom reveals that a pair of jaw-plate are located at the ventral side near the mouth orifice. Each jaw-plate is rather thin, 
chitinized but soft, somewhat semicylindrical in shape, the front part is thick and blackish in colour.

Radula (Text-fig. 10): It is $25 \mathrm{~mm}$ long and $1.8 \mathrm{~mm}$ wide, formula 1.1.1. $\times 53$. The central tooth is thin and elongate quadrate in form (no. 7) but becomes shorter from front to behind. It is asymmetrical, the median longitudinal line is distorted to the left, so that the left half of the tooth is shifted behind; the front margin reflected with a median sharp cusp, and 3-4 denticles on the right margin, but on the left margin they are nearly imperceptible. The lateral tooth is prominently developed; the base and its stem of the tooth stout and dark brown in colour; the base is nearly pentagonal. It is noted that the lateral tooth on the left side is shifted behind from the level of the right lateral tooth, and the stem and cusp intersecting alternately and deeply. The stem is protruded forward in a quadrate form, with several minute wrinkles on the right and left sides. The cusp is long and sharp, sword-like, the tip pointed, with a thin blade in front and behind, in the latter about 17 minute and rather irregular denticles are seen.

The radular sheet is moderately thick, and the side margin does not extend, ending near the base of the lateral tooth.

The stomach is spaceous, with its wall rather thin, and distended with ingested food material. These contents are soft and in irregular forms, variously disintegrated (small granules, thin films, threads, dendrites, etc.), the total may attain about 200 cubic millimeters, light buff or greyish brown in colour. It is known that Lamellaria feeds on colonial tunicates (Fretter \& Graham, 1962, p. 241), so that the stomach contents of this animal may perhaps be derived from the disintegrated body tissues of ascidians, but it is not possible to identify the group or species of the ascidians.

\section{Remarks}

\section{(A) Classifigation}

Classification of the species of this group has been carried out on the morphology of the shell which shows eminent reduction conversely to the development of mantle which covers the shell, and the radula has been known in few species only. It seems natural that the classification should be done based on the characters of both the shell and radula, and the Japanese species of this group are listed in the following.

The shape of this new species is allied to Lamellaria uchidai Habe, 1958, but larger and more rounded in outline, and from L. kiiensis Habe, 1944, this is easily distinguished by the much larger shell, wider aperture and also by the shape of the radular teeth and the animal.

Dr. T. Kuroda formerly identified a shell specimen from Nagasaki in the collection of Mr. Ichirō Kaneko, an eminent collector, as Lamellaria tongana Quoy et Gaimard, 1824, which has a higher spire and more elongate aperture than this species; by these characters tongana should be allocated to Coriocella. The occurrence 
of this species has not been recorded in malacological literature thus far, and I express my thanks for his kind information.

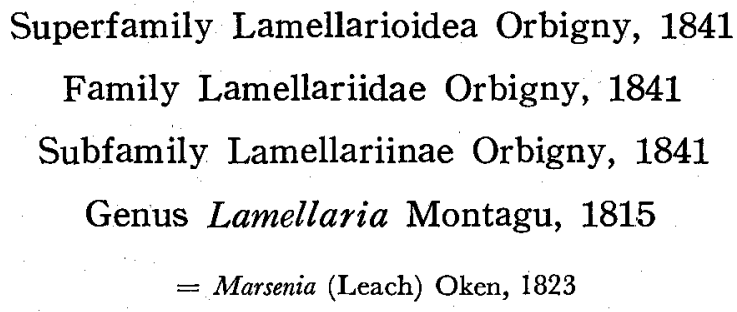

Type: Helix perspicua Linné, 1758

Mantle convex, arcuated, thick, tubercular, anterior fold median. Shell spiral, thin, pellucid; spire tumid, small; columella greatly receding; aperture very large, entire (H. \& A. Adams, 1853).

Radula: Central tooth mostly bifurcated behind; lateral tooth large and strong, with a cusp which is up-covering, pointed, mostly toothed on both sides, marginal tooth missing (Thiele, 1929).

Species occurring in Japan:

Lamellaria kiïensis Habe, 1944 (Kishn bekkō-tamagai)

Habe, 1944, pp. 201-203, textfigs. 2-5; Ditto, 1961, p. 40, pl.18, fig. 18;

Ditto, 1964, p. 64, pl.18, fig. 18; Biol. Lab. Imp. Househ., 1971, pp. 140, 92, pl. 108, fig. 16.

(Type-locality) Bansho-zaki, near Seto Mar. Biol. Lab. of Kyoto Univ., Shirahama, Wakayama Pref.; Honsha (Bōsō Peninsula as north limit), Shikoku and Kyusha. On rocky and gravelly bottom between tide marks down to $60 \mathrm{~m}$ deep.

Lamellaria uchidai Habe, 1958 (Uchida bekkō-tamagai)

Habe, 1958a, p. 14, pl. 1, fig. 11. Eel-grass meadow near the Akkeshi Mar. Biol. Station of Hokkaido Univ., Hokkaido.

Lamellaria utinomii Taki, $\mathrm{n}$ sp. (Ibo bekkō-tamagai, nom. nov.)

(here described) Tōshima, Shirahama, Wakayama Pref.

"Marsenia sp."

Habe \& Ito, 1965, p. 22 (with a figure). Hokkaido. Explanation of shell is given, but unnamed.

Lamellaria perspicua (Linné, 1758) (?)

Bergh (1905, p. 110) described: "Ein kleines, nur $4 \mathrm{~mm}$ langes, der typischen Marsenia wahrscheinlich angehörendes Individuum wurde im Juli 1893 von Herrn Ingenieur Schönau an $33^{\circ} 5^{\prime}$ N.B. $128^{\circ} 22^{\prime}$ Oe. L. im japanischen Meere (zwischen Wladiostock und Nagasaki) aus einer Tiefe von 25 Faden gefischt. Dieses (männliche) Individuum war ganz weiss mit sehr deutlich durchschimmernder Schale und ganz ebenem Rücken." The location is about $60 \mathrm{~km} \mathrm{NW}$ of Fukue Harbour, Goto Islands. The above specimen may be juvenile (adult $16 \mathrm{~mm}$ shell length) and species identification difficult; but according to Fretter \& Graham (1962, p. 667) the occurrence of this species is "throughout Northern Hemisphere." This record has been unnoticed by Japanese workers; as to this species a future study is needed. Lamellaria latens (Müller, 1776) was listed by Kira (1964, p. 99 ) and Shimizu (1971, p. 72) as occurring in the central Honshu, but should be deleted from the Japanese fauna. The state of things is as follows: 
Dr. T. Kuroda recently told me that, formerly he thought that a small Lamellariid shell from Wakayama Prefecture may be tentatively referable to this species and informed Mr. Kira about this, who listed so in his hand-list and mimeographed. The species in question was later described as new (L. kiiensis) by Dr. Habe in 1944. L. latens is widely distributed in Western Europe, namely from Norway, England to the Mediterranean Sea, but not in Japanese seas.

\section{Genus Coriocella Blainville, 1824 \\ $=$ Chelinotus Swainson, 1840 \\ $=$ Chelyonotus Herrmannsen, 1846 \\ = Chelynotus Bergh, 1853; Marshall, 1873}

Type: Lamellaria (Coriocella) nigra Blainville, 1824

Shell resembling Lamellaria s. str., but discriminable by a higher spire, in ventral view the interior of the spire with 3 volutions can be seen.

Radula: central tooth $\wedge$-shaped, with a single median cusp, lateral tooth with a single cusp on the anterior side and none on the posterior side.

Species occurring in Japan:

Coriocella setoensis (Habe, 1944) (Seto bekkō-tamagai)

Habe, 1944, p. 201, text-fig. 1; Ezura, Shirahama, Wakayama Pref.

Habe, 1958, pp. 49, 57, pl. 2, fig. 12.

Coriocella mauritiana (Bergh, 1875) var. (Obekkō-tamagai)

Tryon, 1886, p.62, pl. 27, fig. 17; Kuroda \& Habe, 1952, p. 50.

Mauritius; Ryukyu, Nagasaki, Wakayama Pref.

Coriocella tongana (Quoy et Gaimard, 1824)

Tryon, 1886, p. 62, pl. 26, fig. 11, pl. 27, figs. 14-15.

Tonga Tabu; East China Sea (Kuroda, MS.)

"Coriocella" punctata Stimpson, 1855

Stimpson, 1855, p. 378; Kuroda \& Habe, 1952, p. 61.

Amami-Oshima.

According to the original description, the animal is"oblong-oval, everywhere covered with flakewhite punctae; mantle smooth; tentacula linear, very long and slender; foot somewhat longer than the mantle" Length (of body) $18 \mathrm{~mm}$. It is unfigured and no account on the shell is given. "Tryon (1886, p. 63) merely listed this species in the genus Lamellaria in his monograph, but gave no description about it. Whether this species should be allocated to Lamellaria or Coriocella can not be decided without the detailed knowledge of the shell and radula.

\section{(B) Radula}

It is noteworthy that structure of the radula of the present new species is asymmetrical. . This peculiarity consists in that,

(1) the transverse series of tooth is obliquely located, the left side element is shifted behind in comparison with the right side element,

(2) the central tooth is obliquely distorted, the position of the main cusp being dislocated leftward from the median longitudinal axis about $10^{\circ}$ in angle, and also the 
number of minor denticles on the left side is less numerous than the right side.

(3) though the size and form of the lateral tooth is equal on each side, the left one is located behind the transverse axis (a perpendicular line to the median longitudinal axis) of the right side, so that the cusp alternately intersects.

The radula of this family has been figured by previous authors (Text-figs. 11-18),
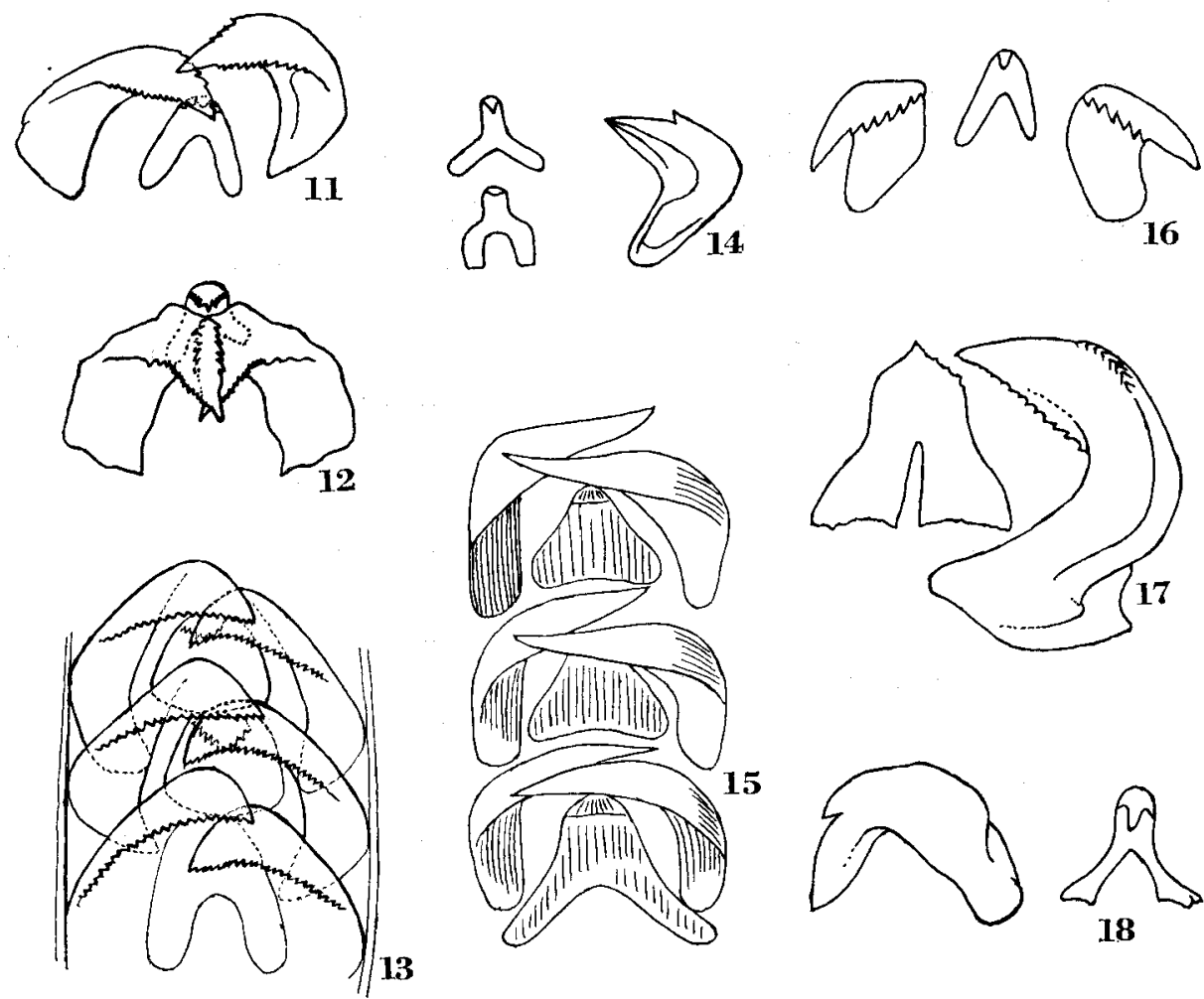

3
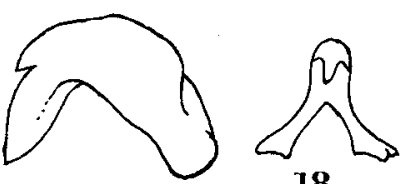

18

Text-figs. 11-18. Radulae of Lamellariidae copied from various authors.

11. Lamellaria kiiensis Habe, 1944 (Habe, 1944, fig. 3)

12. Lamellaria (= Marsenia) producta (Leach, 1842) (Troschel, 1861, pl. 16, fig. 4)

13. Lamellaria (= Marsenia) perspicua (Linné, 1758) (loc.cit. pl. 16, fig. 3)

14. Coriocella setoensis (Habe, 1944) (Habe, 1958, pl. 2, fig. 12)

15. Coriocella (= Chelyonotus) tongana (Quoy et Gaimard, 1824) (Troschel, 1861, pl. 16, fig. 5)

16. Coriocella ophione (Gray, 1849) (Hutton, 1883, pl. 13, fig. w)

17. Coriocella nigra (Blainville, 1825) (Vayssière, 1911, pl. 11, fig. 167)

18. Djiboutia verrucosa Vayssière, 1911 (loc. cit, pl. 11, fig. 174)

but the asymmetrical structure seems to have been overlooked, especially it is not easy to find the asymmetry of lateral tooth by figuring one side element. It is concluded that in the genus Lamellaria both the central and lateral teeth show asymmetrical structure but in the genera Coriocella and Djiboutia they are symmetrical, or asymmetrical in a low degree. 
The structure of the radula of the Mollusca, especially the form and position of each tooth, is symmetrically arranged. The only exception to this rule is found in the Octobrachiata (=Octopoda), in which the cusps (ectocones) of the central tooth (except the mesocone) shows bilateral asymmetry, the position of the cusp gradually dislocates from anterior to posterior so that its position can be traced in an oblique line serially. This asymmetry is seen in most families of the Octobrachiata, but no such phenomenon is observed in the lateral and marginal teeth, and also in the Decembrachiata (=Decapoda). At present we do not know the ecological or physiological significance of this asymmetry.

This fact was first noticed by Robson (1925). There are two types of seriation of the radular teeth; "simple symmetrical seriation is indicated by the letter A, asymmetrical by $B$, and the numbers attached to the letter indicate how many teeth are occupied by a series. Thus, $A_{5}$ means that seriation is simple and is completed in five successive teeth." (Robson, 1929, pp. 13-14). But here I am concerned with the asymmetrical $\mathrm{B}$ series.

This seriation is variable according to the difference of species in the Octobrachiata and used in the description of the species, but it is not clear whether the seriation is specific in species or not. Robson (1929, p. 29) showed that he found in the rhachidian tooth of Octopus vulgaris asymmetrical type B in six cases, symmetrical type A in four cases among 21 specimens examined in detail. Adam (1933) also reported his observation on this matter in $O$. vulgaris in detail, including asymmetry of the cusp in the lateral tooth due to malformation, but could not show the origin of the asymmetry.

The fact that the central tooth is completely covered with the lateral tooth is also noteworthy. In the general Gastropod radula the central tooth is seen somewhat isolated from the lateral tooth. Thus it is supposed that the radular caecum itself in this species may have been mechanically narrowed, seemingly a supposed pressure from both sides to the median longtudinal axis made near, which resulted in (a) the covering-over of the central tooth with the lateral tooth, and (b) deep intersection of the lateral teeth on both sides, and also (c) the distortion of the longitudinal axis of the central and lateral tooth. Among these items, cases of (a) and (b) are seen in figures of previous authors, such as in Lamellaria kiiensis, producta, perspicua and Coriocella tongana (Text-figs. 11-13, 15).

Of course, this is a mere surmise, and I do not know the origin and physiological meaning, for example, whether there is a benefit or not for the mastication of food material by the paritcular narrowing (resulting in the asymmetrical structure) of the radular caecum.

Asymmetry of the central tooth was noticed by Bergh (1905, p.111) in Lamellaria diegoensis (Dall) (Locality: N.W. coast of Tasmania), saying "das linke Bein meistens ein wenig länger als das rechte (Fig. 31)," and also in Coriocella patagonica (E.A. Smith) (?) (Locality: Fiji Islands), “ Die medianen Platten .........die Schenkel ungleich 
lang, der rechte etwas kürzer (Fig. 33)." The same was also described by Vayssière (1911, p. 120) in Coriocella nigra (Blainville)(Locality: Aden, Red Sea), saying, "... ......les dents médianes semblent être en voie de régression, elles sont un peu asymétriques dans la forme générale et surtout par l'absence de denticules sur le côté droit de la cuspide (côté gauche sur notre dessin, fig. 167 (Text-fig. 17), représentant la face concave d'une de ces dents)," and though he took into account concerning the absence of denticles on its right side, it is not clear why the central tooth is in the way of regression, and also he did not show the asymmetry of the lateral tooth. In conclusion, this asymmetry has been noticed only fragmentarily thus far, and the structure of the lateral teeth seems unnoticed.

This conjecture might be extended to the fact that, in this species the radula may no be used for mastication so that it is in the way of disuse and atrophy, because

(1) the radular caecum is very narrow in comparison with the ordinary Gastropods; it is nearly straight, the hind part showing only a short loop.

(2) there is no musculature on the bottom of the radula, by which each tooth can move to rasp the food.

(3) in this radula no defacement of the cusp is seen in the teeth of earlier part; the blade of each tooth is perfect and intact in the entire length of the radula.

(4) in the end part 7 teeth are thin in colour and nearly transparent, but the shape of the teeth is the same as those of earlier part. As a rule the teeth of the end part is smaller and incomplete in shape; these facts show that they are in the way of teeth formation. In this case this process of formation is not observed.

(5) abnormal teeth in which the terminal part of the blade of the lateral tooth is crooked like a spoon are seen in many cases in the anterior half of the radula; in one case (left side, no. 36) a tooth is crooked backward at right angle. These facts seem to show that they have not been used for mastication of food. A similar curving of the lateral teeth is also seen in Coriocella tongana (Text-fig. 15).

From the above, it is conjectured that though the animal has an apparently ordinary radula, which show very fine structure in each tooth, but the radular caecum became too narrow to allow rasping of food, so that the food has been scraped off mostly by the mandible only; the fact that the contents in the stomach are composed of particles of various sizes seem to explain this supposition.

Ludwig (1932) summarized various cases of asymmetrical structure in the animal body, and asymmetrical structure in this case corresponds to "Asymmetrie infolge schlangenähnlicher Gestalt (p. 238)," namely, in very elongated body (Gymnophiona, several Urodelas, snakes and some Saurids) visceral organs such as kidney, gonad and lung which lie in side-by-side position change to anterior-posterior position.

(C) Rarity of the Specimen.

It is well known that animals of the genus Lamellaria feed on colonial tunicates, which are commonly found on the rocky shore. However, these animals may be fairly 
stenophagous, namely a certain species may feed on a limited number of species or a particular species. Therefore the life of Lamellaria species depends so much on the existence and moreover the condition of abundance or paucity of tunicates, that the condition of distribution and abundance is very limited. For example, L. perspicua (Linné) feeds on Leptoclinum and Polyclinum (Fretter \& Graham, 1962, p. 262). In so far as my research of literature could ascertain, authors such as Vayssière, Bergh and Habe observed a single specimen in the description of a new species, so that our knowledge is limited within a certain extent, not based on a number of specimens. In conclusion, though animals of this group are widely distributed, they live rather a solitary life, despite that they lay a large number of eggs upon the colonial tunicates on which they feed. It is desired that the mechanism of feeding, especially the rasping movement, will be observed in future, and verify the above conjecture.

\section{REFERENCES}

Adam, W. 1933. Notes sur les Céphalopodes. II. Anomalie de la radula chez Octopus vulgaris Lamarck et observations sur la sériation et l'asymétrie. Bull. Mus. Roy. Hist. Nat. Belg., 9 (3): 1-8.

Adams, H. \& Adams, A. 1858 . The genera of Recent Mollusca, vol. 1. London.

Bergh, R. 1886. Report on the Marseniadae collected by H.M.S. Challenger during the years $1873-76$. Report Sci. Res. Voy. Challenger, Zool., vol. 15: 1-24, pl.1. 1886. Die Marseniaden. Zool. Jahrb. Abt. Syst., 1: 165-176. 1899. Nudibranches et Marsenia provenant des campagnes de la Princesse-Alice (1891-1897). Résult. Camp. Sci. Albert Ier, Prince Souv. Monaco, fasc. 14: 1-45, pls. 1-2.

1905. Opisthobranchiata-Pectinibranchiata. Malac. Unters. 6. Theil, 2. Lief. In Semper: Reisen Archipel Philippinen, Wiss. Res. Bd.9: 57-115, pls. 5-8.

___ 1908. Marseniadae. Appendix zu der Prosobranchiata (Pectinibranchiata). Siboga Expeditie, XLIX ${ }^{1}$ a: $99-107$.

Biological Laboratory, Imp. Household. (ed.) 1971. Sea Shells of Sagami Bay: 140; 92, pl. 108, fig. 16. Maruzen Co., Ltd., Tokyo.

Franc, A. 1968. Classe des Gastéropodes. In Grassé, P.P. (éd.) Trạité de Zool., tom. 5, fasc. 3. Masson Co., Paris.

Fretter, V. \& Graham, A. 1962. British Prosobranch Molluscs. Ray Soc., London.

Habe, T. 1944. Two new species of the genus Lamellaria found in Prov. Kii, Japan. (In Japanese) Venus, 13: 201-203, textfigs. 1-5.

1958. On the radulae of Japanese marine Gastropods (4). Venus, 20: 43-60, pls. 2-3.

1958a. The fauna of the Akkeshi Bay. XXV. Publ. Akkeshi Mar. Biol. Stat. no. 8: 1-39, pls. $1-5$.

1961. Coloured Illustrations of the Shells of Japan, II. Hoikusha, Osaka.

\& Ito, K. 1965. Shells of the World in Colour, vol. 1. The Northern Pacific. Hoikusha, Osaka.

Hutton, F.W. 1883. Notes on some branchiate Gastropoda. Trans. New Zealand Inst., 15: 118-131, pls. 13-16.

Hyman, L. H. 1967. Mollusca, I. The Invertebrates, vol. 6. McGraw-Hill Book Co., New York.

Kira, T. 1946. General List of Recent Marine Shells of Japan. (Mimeographed: In Japanese) Published by the author, Kyoto.

Kuroda, T. \& Habe, T. 1952. Check list and bibliography of the recent marine Mollusca of Japan. Published by L.W. Stach, Tokyo.

Ludwig, W. 1932. Das Rechts-Links-Problem im Tierreich und beim Menschen. J. Springer, Berlin. 
Martens, E. von. 1880. Mollusken. In K. Möbius: Beiträge zur Meeresfauna der Insel Mauritius und der Seychellen: 181-346, pls. 19-22. Gutmann, Berlin.

Nordsieck, F. 1968. Die europäischen Meeres-Gehäuseschnecken (Prosobranchia). G. Fischer, Jena. Pilsbry, H. A. 1895. Catalogue of the marine Mollusks of Japan. Detroit.

Robson, G.C. 1925. On seriation and asymmetry in the Cephalopod radula. J. Linn. Soc. Zool. London, 36: 99-108.

1929, 1932. A monograph of the Recent Cephalopoda. Parts I, II. London.

Shimizu, Masashi. 1971. List of Japanese Shells (In Japanese). Tokyo.

Stimpson, W. 1855. Descriptions of some of the marine Invertebrata from the Chinese and Japanese seas. Proc. Acad. Nat. Sci. Philadelphia, 7: 375-384.

Suter, H. 1913. Manual of New Zealand Mollusca (Atlas of plates, 1915). Wellington, N.Z.

Thiele, J. 1929. Handbuch d. syst. Weichtierkunde. Bd. 1. G. Fischer, Jena.

Troschel, F.H. 1861. Fam. Marseniadae. Das Gebiss der Schnecken, Bd. 1: 185-188, pl. 16.

Tryon, G.W. 1886. Lamellariidae. Man. Conch., vol. 8.

Vayssière, A. Recherches zoologiques et anatomiques sur les Opisthobranches de la Mer Rouge et du Golfe d'Aden. Ann. Fac. Sci. Marseille, tom. 20 (Suppl.), fasc. 2: 1-157, pls. 1-11.

Wenz, W. 1938-1940. Gastropoda. In Schindewolf: Handb. d. Paläozool. Bd. 6, Teil 1.

Postscript. Allan (1958) reported 4 species of Lamellaria from the eastern Australian waters, without giving names to each species, only denoting them L. sp. A, B, C, D. It is concluded that all these species differ widely from the present new species. The asymmetry in the form of radular teeth seems to be seen in L. sp. A (pl. 10, fig. 11) and L. sp. C (median tooth, pl. 12, fig. 9), though nothing is mentioned in the text.

Allan, J. 1958. Some species of Lamellariidae (Class Gastropoda) from the eastern Australian coast. J. Malac. Soc. Australia, No. 2: 48-57, pls. 10-12.

\section{EXPLANATION OF PLATE I}

Lamellaria utinomii Taki, n. sp.

1. Dorsal view, $\times 1.35$

2. Ventral view, $\times 1.35$

3. Dorsal view, dorsal main part of the mantle cut aside to show the shell, $\times 1.16$ 
Publ. Seto Mar. Biol. Lab., XXI (1), $1972 . \quad$ PLATE I
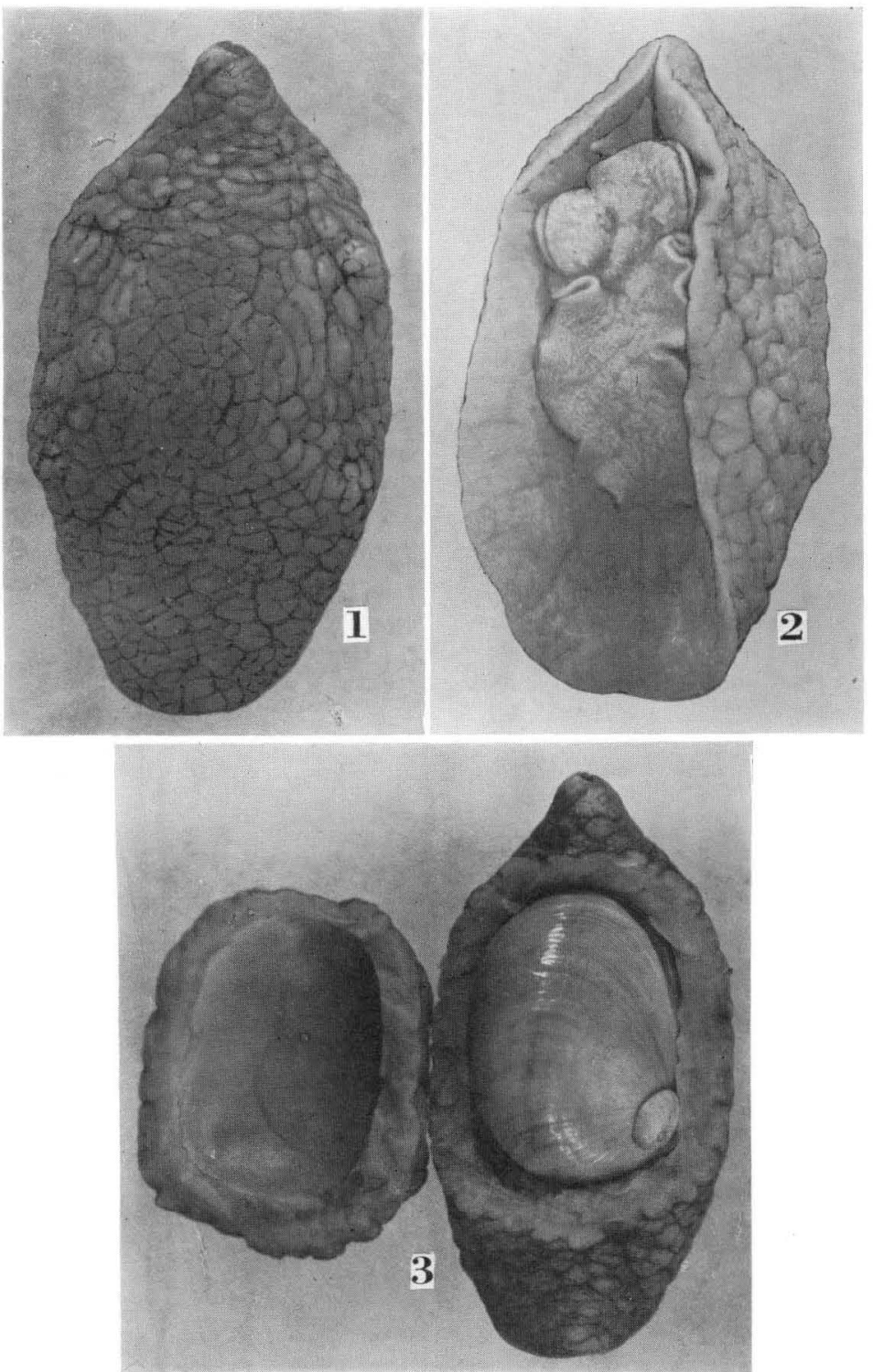

I. TAKI: A New Species of Lamellaria from Japan 